LUCJAN SUCHANEK ${ }^{1}$

\title{
ROSJOZNAWSTWO = KULTUROZNAWSTWO. ROSJOZNAWSTWO NA UNIWERSYTECIE JAGIELLOŃSKIM (1990-2017)
}

Słowa kluczowe: rosjoznawstwo, interdyscyplinarność, wielowymiarowość

Początki krakowskiego rosjoznawstwa sięgają przełomu stuleci XX i XXI, a jego geneza związana jest z Wydziałem Filologicznym Uniwersytetu Jagiellońskiego. Grupa badaczy z Instytutu Filologii Wschodniosłowiańskiej w wyniku długotrwałych i owocnych zabiegów, poprzedzonych głębokimi studiami w różnych dziedzinach i sferach wiedzy o Rosji, powołała do życia rosjoznawstwo jako nową - obok rusycystyki - formę dydaktyki. Jego początki wiążą się ściśle z założonym w 1990 roku Zespołem Badawczym Rosyjska Literatura Emigracyjna i Drugiego Obiegu². Inicjatorem i kierownikiem zespołu był Lucjan Suchanek, a w jego skład wchodzili: Anna Raźny, Lidia Liburska, Andrzej Dudek, Hanna Kowalska-Stus, Katarzyna Duda, Krystyna Pietrzycka-Bohosiewicz (do roku 2000), Andrzej Drawicz (do 1997) i Wasilij Szczukin (do 1995). Dla kształtowania się rosjoznawstwa ważne znaczenie miało - możliwe w wyniku przemian w Polsce po roku 1980 wprowadzenie dzięki inicjatywie prof. Ryszarda Łużnego do programu studiów rusycystycznych najpierw w Krakowie, a potem w wielu innych ośrodkach problematyki sacrum oraz rosyjskiej myśli filozoficznej.

Fundamentalną rolę $\mathrm{w}$ rozwoju rosjoznawstwa odegrały cztery publikacje książkowe pod redakcją Lucjana Suchanka, który do dwu z nich napisał rozbudowane wstępy. W publikacjach tych, choć każdy z autorów

\footnotetext{
${ }^{1}$ Prof. em.; Uniwersytet Jagielloński w Krakowie.

${ }^{2}$ Zespół współpracował z Instytutem Kultury Rosyjskiej i Radzieckiej (Institut für russische und sowjetische Kultur) w Bochum oraz z moskiewskim Instytutem Literatury Światowej Akademii Nauk (Institut Mirowoj Litieratury).
} 
to indywidualność badawcza, zachowane zostały jednolite zasady zbiorowych monografii. Nie są to - jak często bywa - zbiory tekstów poszczególnych naukowców, lecz przemyślana koncepcyjnie i metodologicznie spójna praca kolektywna. Rozpoczyna ją, wydana w 1993 roku, w ówczesnym czasie ze względu na temat unikatowa, Emigracja i tamizdat. Szkice o współczesnej prozie rosyjskiej ${ }^{3}$. Publikację otwierał wstęp Lucjana Suchanka Literatura rosyjska jest tam, gdzie znajdujq się pisarze rosyjscy, po którym umieszczono teksty poświęcone książkom pisarzy trzeciej fali emigracji i samizdatu (pisarzom, którzy nie byli emigrantami, lecz ich dzieła nie mogły się ukazać w Związku Radzieckim i dlatego publikowane były za granicą, w tak zwanym tamizdacie): Aleksandrowi Sołżenicynowi, Aleksandrowi Zinowiewowi, Władimirowi Wojnowiczowi, Georgijowi Władimowowi, Wiktorowi Niekrasowowi, Abramowi Tercowi, Wasilijowi Aksionowowi, Borisowi Pasternakowi, Warłamowi Szałamowowi, Wasilijowi Grosmanowi i Lidii Czukowskiemu4.

Druga książka: Dać świadectwo prawdzie. Portrety współczesnych pisarzy rosyjskich ${ }^{5}$, poprzedzona była wstępem Lucjana Suchanka Świadkowie, oskarżyciele, sprzymierzeńcy i obrońcy. O postawach pisarzy rosyjskich. Poświęcona została Wasilijowi Grossmanowi, Aleksandrowi Sołżenicynowi, Lwu Kopielewowi, Władimirowi Bukowskiemu, Wasilijowi Aksionowowi, Wieniediktowi Jerofiejewowi i Saszy Sokołowowi ${ }^{6}$.

Kolejny tom zatytułowany był Realiści i postmoderniści. Sylwetki współczesnych rosyjskich pisarzy emigracyjnych ${ }^{7}$. Zaprezentowano w nim twórczość Władimira Maksimowa, Władimira Wojnowicza, Eduarda Limonowa, Juza Aleszkowskiego, Friedricha Gorensteina i Aleksandra Galicza ${ }^{8}$.

${ }^{3}$ Emigracja i tamizdat. Szkice o współczesnej prozie rosyjskiej, red. L. Suchanek, Kraków 1993. Książka doczekała się 17 recenzji: w Polsce, we Francji (Maciej Broński - „Kultura Paryska"), Włoszech (Gustaw Herling-Grudziński), w Rosji, Kanadzie (Edward Możejko) i Serbii.

${ }^{4}$ Autorami tekstów (często dwu) byli: Andrzej Drawicz, Andrzej Dudek, Lidia Liburska, Krystyna Pietrzycka-Bohosiewicz, Anna Raźny, Lucjan Suchanek, Wasilij Szczukin.

${ }^{5}$ Dać świadectwo prawdzie. Portrety współczesnych pisarzy rosyjskich, red. L. Suchanek, Kraków 1996.

${ }^{6}$ Autorami tekstów byli: Krystyna Pietrzycka-Bohosiewicz, Lucjan Suchanek, Hanna Kowalska-Stus, Anna Raźny, Lidia Liburska, Andrzej Dudek, Wasilij Szczukin.

${ }^{7}$ Realiści i postmoderniści. Sylwetki współczesnych rosyjskich pisarzy emigracyjnych, red. L. Suchanek, Kraków 1997.

${ }^{8}$ Autorami tekstów byli: Katarzyna Duda, Andrzej Dudek, Hanna Kowalska-Stus, Lidia Liburska, Anna Raźny, Lucjan Suchanek. 
W dorobku krakowskich rosjoznawców ważne miejsce zajmuje tom Wizja człowieka i świata w myśli rosyjskiej. Pojawiło się w nim dwoje nowych autorów - Lidia Macheta i Joachim Diec. Publikacja prezentuje różne aspekty życia człowieka jako jednostki i osoby, a także jako członka społeczeństwa, człowieka w indywidualnym i społecznym wymiarze. Ilustrując to zjawisko, autorzy tekstów sięgają do średniowiecza, do stulecia XIX (Nikołaj Danilewski, Lew Tołstoj), do epoki radzieckiej i postradzieckiej (Wiaczesław Iwanow, Paweł Fłorienski, Aleksander Zinowiew, Władimir Maksimow ${ }^{10}$.

Oprócz prac zbiorowych charakterystycznym gatunkiem rosjoznawców krakowskich stały się monografie ${ }^{11}$. Do 2001 roku ukazały się następujące publikacje: L. Suchanek, Aleksander Sołżenicyn. Pisarz i publicysta (1994), H. Kowalska-Stus, Kultura staroruska. Tradycja i zmiana (1998), K. Pietrzycka-Bohosiewicz, W poszukiwaniu autentyzmu. Twórczość prozatorska Georgija Władimowa (1999), A. Raźny, Literatura wobec zniewolenia totalitarnego. Warłama Szałamowa świadectwo prawdy (1999), L. Suchanek, Homo sovieticus, "świetlana przyszłość", "gnijqcy Zachód”. Pisarstwo Aleksandra Zinowiewa (1999), A. Dudek, Wizja kultury w twórczości Wiaczesława Iwanowa (2000), K. Duda, Wiara i naród. Twórczość Władimira Maksimowa (2001), L. Suchanek, Parias i heros. Twórczość Eduarda Limonowa (2001).

Monografie te, jak wymienione wcześniej prace zbiorowe, wypływały z podobnych źródeł inspiracji metodologicznych, pozwalających opisać w pełni i wszechstronnie twórczość pisarzy rosyjskiej emigracji i tamizdatu ${ }^{12}$. W każdej z prac poruszone zostały trzy główne problemy stanowiące fundament radzieckiej rzeczywistości: człowiek, system i państwo. $W$ badaniu tych zagadnień potrzebne było nowe podejście, odmienne od czysto filologicznego, a pozwalające ukazać jednostkę i ideologię systemu, którego celem było stworzenie nowego człowieka i nowego państwa. W systemach totalitarnych i kolektywistycznych, do jakich należał realny komunizm, mamy do czynienia nie z wolnością w sensie ontologicznym, lecz z wolnością - przy czym niepełną lub wręcz iluzoryczną - jedynie ekonomiczno-społeczną czy prawną. Jak zauważa Stanisław Kowalczyk, każdy

${ }^{9}$ Wizja człowieka i świata w myśli rosyjskiej, red. L. Suchanek, Kraków 1998.

${ }^{10}$ Autorami tekstów byli: Joachim Diec, Katarzyna Duda, Andrzej Dudek, Hanna Kowalska-Stus, Lidia Liburska, Lidia Macheta, Anna Raźny, Lucjan Suchanek.

${ }^{11}$ Terminu „monografia” używam w jego tradycyjnym rozumieniu.

${ }^{12}$ Książka Hanny Kowalskiej-Stus podejmowała inną problematykę i jako pierwsza z publikacji krakowskich rosjoznawców była pracą kulturoznawczą sensu stricto. 
totalitaryzm jest patologiczną formą państwa i świadomie dąży do zniewolenia człowieka ${ }^{13}$. Egzystencja w systemie, którego dominującym elementem staje się kolektyw, wymusza podporządkowanie się komunalne, wynikające z braku możliwości wyboru. Pozbawiony środków realizacji celów społecznych, człowiek przestaje być niezależny w stosunku do społeczeństwa, państwa i systemu. $\mathrm{W}$ radzieckiej nauce i propagandzie człowiek przedstawiany był nie jako jednostka i osoba, lecz wyłącznie jako członek kolektywu, społeczeństwa - ens sociale. Wąsko socjologiczne podejście do opisu człowieka, jakim posługiwała się nauka i propaganda radziecka, było nieprzydatne lub mało przydatne $w$ badaniach prowadzonych przez krakowskich rosjoznawców. W naturalny więc sposób ich studia ukierunkowane zostały antropologicznie, w stronę filozofii człowieka, co pozwoliło na pokazanie prawdziwego oblicza jednostki nazwanej homo sovieticus.

Należy ponadto podkreślić, że system radziecki był ateistyczny: propagandę ateistyczną prowadziło państwo i w efekcie ateizm ze zjawiska indywidualnego stawał się masowy i wojujący ${ }^{14}$. W kraju odbierającym człowiekowi wolność paradoksalnie głoszono wolność człowieka od religii i Cerkwi jako instytucji ograniczającej jakoby wolną wolę. W takiej sytuacji nie mogło być miejsca dla wiary i eschatologicznych pragnień.

Chcąc zrozumieć genezę krakowskiego rosjoznawstwa i jego specyfikę, trzeba na nie spojrzeć w kontekście nauki o Słowianach ${ }^{15}$, a więc slawistyki, która na uniwersytetach ukształtowała się jako dyscyplina filologiczna. Obok terminu "slawistyka”, używanego na uczelniach, w nauce funkcjonuje także inny: "słowianoznawstwo", występujący między innymi w nazwie jednego z komitetów PAN - Komitet Słowianoznawstwa. Przez wielu obie te nazwy traktowane są synonimicznie, jeśli jednak chodzi o zawartość pojęcia, nie są one tożsame.

Struktura studiów slawistycznych na uczelniach oparta została na tradycyjnych zasadach organizacji procesu dydaktycznego. Slawistyka tworzona więc była na wzór istniejących wcześniej dyscyplin filologicznych, takich jak germanistyka, anglistyka czy romanistyka, i ograniczana do języka i literatury. Jednak z biegiem lat na wielu uczelniach filologia, w szczególności

${ }^{13}$ Ks. S. Kowalczyk, Człowiek a społeczność. Zarys filozofii społecznej, Lublin 1994, s. 164.

${ }^{14}$ Ks. T. Pikus, Rosja w objęciach ateizmu, Warszawa 1997.

${ }^{15}$ L. Suchanek, Sławianie i sławistika w epochu głobalizacii, „Slavistika” XVIII, 2014 (Belgrad), s. 113-126. 
slawistyka (zwłaszcza rusycystyka), zaczynała przybierać nieco inne oblicze. Zarówno więc dydaktyka, jak i związane z nią badania zaczęły wychodzić poza krąg tradycyjnych przedmiotów i tematów filologicznych. Rzecz jasna, na uczelniach możliwy jest model slawistyki, w której znajdą się wyłącznie problemy języka (różne typy gramatyk - opisowa, kontrastywna, historia języka, gwary, teoria języka, językoznawstwo porównawcze, język cerkiewno-słowiański) i literatury (historia literatury, wstęp do literaturoznawstwa, poetyka, wersologia, analiza dzieła literackiego).

Etap pośredni na drodze do takiego modelu dydaktyki i badań, jakim jest rosjoznawstwo, to znaczy model bardziej rozbudowany, lecz jeszcze filologiczny - dziś w polskim systemie edukacyjnym dominujący - to filologie, w których do podanych wyżej dyscyplin (niektóre z nich zostają odrzucone) dochodzi historia, historia sztuki, historia kultury (rozumianej z reguły jako historia rozmaitych sztuk) ${ }^{16}$.

Żeby zrozumieć, na jakim fundamencie powstało rosjoznawstwo, musimy przyjrzeć się zakresowi badań słowianoznawczych. W słowniku Brockhausa i Efrona czytamy: „Słowianoznawstwo, slawistyka to nauka o Słowiańszczyźnie jako całości i w szczególności o każdym członku rodziny słowiańskiego plemienia"17. Studia nad kulturami konkretnych narodów słowiańskich spowodowały konieczność utworzenia nowych terminów dotyczących zakresu dydaktyki i badań, takich jak rusycystyka, bohemistyka, bułgarystyka, słowacystyka, polonistyka itd. ${ }^{18}$

Krakowskie rosjoznawstwo jest propozycją badań i studiów skoncentrowanych na - by posłużyć się słowami ze słownika Brockhausa i Efrona - jednym „członku rodziny słowiańskiego plemienia”. Wpisuje się więc ono $w$ tradycję badań słowianoznawczych, które słownik ten definiuje następująco:

słowianoznawstwo - to nauka o Słowianach, łącząca szereg dyscyplin naukowych, zajmujących się historią, literaturą, językiem, folklorem, etnografią, ekonomiką, sztuką, religią [...] zabytkami kultury materialnej i duchowej Słowian ${ }^{19}$.

${ }^{16}$ Idem, Litieraturowiedienije i kulturołogija, „Sborník Prací Filozofické Fakulty Brněnské Univerzity" X 8, 2005, s. 127-130.

17 Энциклопедический словарь Ф.А. Брокгауза и И.А. Ефрона, С-Пб. 1889-1907, http://dic.academic.ru//dic.nsf/brokgauz_efron/94811 (tłum. moje - L.S.).

${ }^{18}$ Polonistyka w Polsce nie jest uznawana za slawistykę, natomiast w kontekście międzynarodowym jest tak - co zrozumiałe - traktowana.

${ }^{19}$ Энциклопедический словарь..., ор. cit. 
W odniesieniu do rosjoznawstwa należy jednak podkreślić istotną różnicę między definicją a rzeczywistością. Autorzy słownika mówią o różnych dyscyplinach naukowych, z reguły autonomicznych, w przypadku zaś rosjoznawstwa rzecz ma się inaczej: to nie suma poszczególnych dyscyplin, lecz jedna dyscyplina, wykorzystująca różne dyscypliny i w różnym stopniu.

Krakowskie studia rosjoznawcze są spojrzeniem na Rosję z perspektywy rozmaitych dyscyplin. Nowością na tle dotychczas istniejących studiów slawistycznych jest to, że dyscypliny te zostały ze sobą połączone i stanowią spójną całość - są nową propozycją w ofercie bogatych studiów slawistycznych. Trzeba jednak odnotować, że nie wszyscy slawiści skłonni są tak szeroko rozumieć slawistykę/słowianoznawstwo. Niektórzy z nich, nazwijmy ich immanentystami, stoją na stanowisku, że ogólny przedmiot badań, jakim są Słowianie, powinien być podzielony pomiędzy przedstawicieli różnych dyscyplin. Dowodzą, że słowiańską filozofię winni badać filozofowie, myśl religijną i historię życia kościelnego (cerkiewnego) - religioznawcy, idee i ideologię - politologowie. Listę tę można znacznie wydłużyć. W tym przypadku jednak filozofowie badający filozofię słowiańską czy religioznawcy badający problematykę religijną u Słowian nie stają się slawistami, lecz pozostają nadal filozofami i religioznawcami.

Z kolei rosjoznawcy, stronnicy interdyscyplinarnego podejścia do nauki, nie widzą sprzeczności w tym, że słowiańską filozofię, myśl religijną i polityczną, a także inne sfery wiedzy o Słowianach mogą badać slawiści/rosjoznawcy, będący z wykształcenia slawistami filologami. Rzecz jasna, mogą to robić tylko ci spośród nich, którzy są do tego odpowiednio przygotowani, drogą bowiem samodzielnych studiów osiągnęli wysoki poziom kompetencji kulturoznawczych.

Na konferencji naukowej w Opolu „Zmierzch Herdera. Filologiczne podstawy slawistyki" prezentowane przeze mnie studia rosjoznawcze prof. Jacek Baluch proponował uznać za alternatywę wobec tradycyjnej slawistyki ${ }^{20}$. W rzeczy samej nie jest to jednak alternatywa, lecz nowy etap w ewolucyjnym rozwoju rusycystyki (slawistyki). W ten sposób studia z dyscypliny wąsko filologicznej stały się kulturoznawczymi.

${ }^{20}$ Zmierzch Herdera. Filologiczne podstawy slawistyki, red. J. Baluch, A. Pająk, Opole 2010. 
Przypatrzmy się przeto związkom rosjoznawstwa jako formy slawistyki (jako kierunku filologii) i kulturoznawstwa. Obie są formami poznania, formami wiedzy i działalności naukowej, jak również formami dydaktyki uniwersyteckiej. Slawistyka ma względnie długą już tradycję; kulturoznawstwo stosunkowo niedawno zyskało status kierunku studiów, wchodząc na stałe do systemu edukacyjnego. Jego celem jest objaśnianie fenomenu kultury, jej roli w życiu i działalności człowieka. Mówi ono o podstawowych wartościach, typach i formach kultury oraz prawidłowościach jej funkcjonowania. Bada przemiany systemu aksjologicznego, transformację mentalności, opisuje nowe rodzaje i odmiany praktyki duchowej. W dzisiejszej nauce polskiej i w praktyce uniwersyteckiej kulturoznawstwo nie ma jednoznacznej, akceptowanej powszechnie definicji i jego zakres jest bardzo różnie rozumiany, nieraz niezwykle wąsko. Sto kilkadziesiąt definicji kultury komplikuje refleksję nad tym zagadnieniem.

W naszych czasach trzy zwłaszcza dyscypliny wpłynęły na charakter badań nad Rosją, które spowodowały, że rosjoznawstwo stało się dyscypliną kulturoznawczą. Należy do nich antropologia (filozofia człowieka) - dział filozofii, w którym człowiek występuje jako specjalny przedmiot poznania. Mówi ona o stosunku człowieka do świata, o jego działaniu w świecie, o doświadczeniu duchowym osoby i formach jej doskonalenia. Antropologia filozoficzna, podobnie jak literatura, stara się odpowiedzieć na pytanie, kim jest człowiek. I to właśnie pomagało zbliżeniu wymienionych wyżej dyscyplin.

Analogicznie jest w przypadku związków z aksjologią. Aksjologia to dziedzina wiedzy filozoficznej - teoria wartości. Jest to nauka o naturze wartości, ich miejscu w rzeczywistości, w egzystencji człowieka. Analiza wartości jest szeroko wykorzystywana przy analizie tekstów literackich. Opisywane są i interpretowane ważne elementy struktury wewnętrznej osoby, utrwalone dzięki jej doświadczeniom życiowym, z całokształtem przeżyć jednostki. Badane są elementy regulujące i determinujące motywację człowieka, jego aksjologiczne zorientowanie.

Niezwykle silny jest związek badań rosjoznawczych z historią idei. Literatura wyraża poglądy i idee, w których uświadamiany jest i oceniany stosunek ludzi do rzeczywistości i stosunek człowieka do drugiego człowieka. Literatura z reguły jest ściśle związana z określonymi koncepcjami, kierunkami i ideologiami. Warto przy tym zaznaczyć, że od dłuższego już czasu uwagę badaczy przyciąga sfera sacrum. Jak czytamy we wstępie do książki Człowiek - dzieło-sacrum: 
nie ma kultury bez sacrum. Jest ono obecne w całej historii człowieka, we wszystkich jej wymiarach, w jego staraniach o zapanowanie nad światem przyrody i kultury oraz w wysiłkach, by te światy poznać i zrozumieć ${ }^{21}$.

W ostatnich latach w badaniach slawistycznych dokonuje się wyraźne przesunięcie. Wymienione wyżej dyscypliny przestają być jedynie narzędziem opisu i interpretacji literatury, następuje ich autonomizacja i w efekcie one same stają się przedmiotem badań slawistów/rosjoznawców.

Taka forma badań i nowy wymiar dydaktyki nie mieściły się w tradycyjnej filologii na Wydziale Filologicznym. Dlatego 24 stycznia 2004 roku Lucjan Suchanek zwrócił się z następującą prośbą do JM Rektora UJ, prof. dra hab. Franciszka Ziejki:

W związku z utworzeniem w Uniwersytecie Jagiellońskim Wydziału Studiów Międzynarodowych i Politycznych zwracam się z uprzejmą prośbą o powołanie w Instytucie Studiów Regionalnych tego Wydziału Katedry Rosjoznawstwa. Nasza wiedza o Rosji, jej kulturze, narodzie, społeczeństwie, państwie, mentalności jest niewystarczająca, a potrzeby duże - zainteresowanie Rosją nie słabnie i Uniwersytet Jagielloński nie może tej potrzeby nie zauważyć. Obowiązkiem Uniwersytetu jest przygotowanie specjalistów posiadających wszechstronną wiedzę, którzy będą przydatni w różnych dziedzinach współpracy między Polską a Rosją, zarówno w wymiarze politycznym, jak i kulturowym. Ważne jest rozwijanie badań nad szeroką i złożoną problematyką rosjoznawczą.

Rosjoznawstwo dobrze mieściło się w ramach nowego wydziału, który łączył aspekt międzynarodowy z politologicznym. Aspekt międzynarodowy był nastawiony na badania nad poszczególnymi krajami oraz grupami krajów i narodów, które stanowiły pewną, różnie definiowaną, wspólnotę. W przypadku studiów i badań międzynarodowych osnową stały się kultury, natomiast zagadnienia stricte polityczne, i wyłącznie one, były domeną drugiego składnika nazwy wydziału - politologicznego.

ZWydziału Filologicznego na nowo powołany w strukturach Uniwersytetu Jagiellońskiego wydział przeszły następujące osoby: prof. zw. dr hab. Lucjan Suchanek, prof. dr hab. Anna Raźny, dr hab. Aleksy Awdiejew, dr hab. Hanna Kowalska, dr hab. Lidia Liburska, dr Joachim Diec, dr Katarzyna Duda, dr Andrzej Dudek, mgr Lidia Macheta.

${ }^{21}$ Człowiek - dzieło - sacrum, red. S. Gajda, H. Sobeczko, Opole 1998, s. 9. 
Rosjoznawstwo ze względu na swój interdyscyplinarny charakter zatrudniało badaczy z różnych dziedzin, dominowali jednak kulturoznawcy, często z wykształcenia filologowie. Ze względu na program potrzebni byli także historyk, geograf i politolog (kompetencji takich rosjoznawcy, którzy przeszli na nowy wydział, nie posiadali). Etatowo związał się z katedrą, przechodząc z Wydziału Historycznego, historyk Mieczysław Smoleń. Ze względu na pensum istniała bowiem konieczność zatrudnienia osób spoza katedry (tzw. wykłady usługowe). Tak było w przypadku geografii, którą wykładał pracownik Instytutu Geografii, i krótko - ekonomii (gospodarki). Z kolei zajęcia z politologii prowadziła osoba zatrudniona w Instytucie Nauk Politologicznych.

Katedra Rosjoznawstwa działała jako jednostka w obrębie Instytutu Studiów Regionalnych do roku 2004. W jej skład wchodziło 14 osób: jeden profesor zwyczajny, jeden profesor nadzwyczajny, dwóch profesorów uczelnianych, pięciu doktorów habilitowanych, dwóch doktorów i trzech magistrów - lektorów. W tym czasie z Wydziału Filologicznego do Instytutu Studiów Regionalnych przeszli ukrainiści/ukrainoznawcy i powstała Katedra Ukrainoznawstwa licząca siedem osób: profesor nadzwyczajny, doktor i czterech asystentów ze stopniem magistra oraz magister, który był lektorem. Samodzielne istnienie dwóch katedr, z których jedna, ukrainoznawstwa, miała słabą kadrę, było w zaistniałej sytuacji ze względu na strukturę instytutu i wydziału nieuzasadnione. Zwróciłem się w związku z tym do ówczesnego dziekana wydziału, prof. Wiesława Kozub-Ciembroniewicza, z wnioskiem o utworzenie na wydziale nowej jednostki: Instytutu Rosji i Europy Wschodniej. W uzasadnieniu pisałem:

Instytut o tej nazwie obejmować będzie badania i specjalności nauczania poświęcone problematyce wschodniosłowiańskiej, głównie rosjoznawstwu i ukrainoznawstwu oraz w perspektywie białorutenistyce. W dobie dzisiejszej, gdy Polska weszła do struktur europejskich, a Słowianie Wschodni pozostają poza nimi, badania w tej dziedzinie i studia uniwersyteckie są szczególnie ważne - istnieje społeczne zapotrzebowanie na znawców tej problematyki.

Wkrótce po powołaniu instytutu kierujący ukrainoznawstwem prof. Włodzimierz Mokry uznał jednak, że z powodów ideowych (ideologicznych) studia nad Rosją i Ukrainą nie mogą być łączone w ramach jednej jednostki organizacyjnej. Stanowisko takie było z merytorycznego punktu 
widzenia nielogiczne i niepraktyczne z przyczyn organizacyjnych oraz strukturalnych. Mimo to prof. Mokry zdołał - wbrew wszelkim uzasadnieniom doprowadzić do wyłączenia z Instytutu Rosji i Europy Wschodniej Katedry Ukrainoznawstwa. W ten sposób nazwa Instytut Rosji i Europy Wschodniej, która miała pomóc i pomogła w przejściu ukrainistów/ukrainoznawców z Wydziału Filologicznego na Wydział Studiów Międzynarodowych i Politycznych, stała się nieadekwatna.

Przejście na inny wydział otwarło nowy etap w dziejach krakowskiego rosjoznawstwa, które - gdy idzie o dydaktykę - w praktycznie niezmienionej formie przetrwało do roku 2012, kiedy kadencję dyrektora zakończyła prof. Anna Raźny. Metodologicznie ten etap był jednolity, jeśli idzie o założenia badawcze. Pokazana wyżej perspektywa antropologiczna i zasady metodologiczne były kontynuowane $w$ dalszych pracach krakowskich rosjoznawców. Zwiększyła się wydajnie liczba pracowników i publikacji, zarówno indywidualnych, jak i zbiorowych.

Liczba pracowników zatrudnionych w instytucie zaczęła rosnąć; uzyskiwali oni stopnie i tytuły naukowe. Tytuł naukowy profesora otrzymali: Hanna Kowalska-Stus, Lidia Liburska, Katarzyna Duda, Joachim Diec; stopień doktora habilitowanego: Małgorzata Abassy, Dymitr Romanowski, Jerzy Gordziejew (białorutenista); stopień doktora: Lidia Macheta, Bartłomiej Brążkiewicz, Martyna Kowalska, Agnieszka Malska-Lustig, Anna Jach, Agata Krzywdzińska, Katarzyna Kosowska, Michał Kuryłowicz, Marta Lechowska, Leszek Madej, Elżbieta Żak ${ }^{22}$. Na emeryturę odeszło czworo profesorów: Lucjan Suchanek, Aleksy Awdiejew, Anna Raźny, Mieczysław Smoleń.

$\mathrm{Na}$ obecnym etapie w strukturze instytutu znajdują się trzy katedry i dwa zakłady. Są to Katedra Rosjoznawstwa (jeden profesor, czterech doktorów, dwóch magistrów - nauczycieli języka), Katedra Kultury Bizantyńsko-Prawosławnej (jeden profesor, jeden doktor habilitowany, jeden doktor), Katedra Badań nad Obszarem Euroazjatyckim (jeden profesor, jeden doktor habilitowany, trzech doktorów), Zakład Antropologii Kultury Rosyjskiej (jeden profesor, jeden doktor habilitowany, dwóch doktorów) oraz Zakład Nowożytnej Kultury Rosyjskiej i Teorii Systemów Kultury (jeden doktor habilitowany, dwóch doktorów).

${ }^{22}$ W wykazie niniejszym pomijam uczestników studiów doktoranckich, którzy uzyskali stopień doktora. 
Od roku 2002 dorobek naukowy rosjoznawstwa wzbogacił się o kilkadziesiąt monografii ${ }^{23}$. Opublikowanych zostało 13 prac zbiorowych, w tym podręcznik akademicki Rosjoznawstwo ${ }^{24}$.

${ }^{23} \mathrm{~W}$ internetowym wykazie dorobku pracowników instytutu brak kilku pozycji! Publikacje (uzupełniając braki w wykazie, o którym wyżej) podaję w porządku alfabetycznym nazwisk autorów, przy czym najpierw wymieniam prace najnowsze: M. Abassy, Russian Mason on the Paths of his Native Culture. The Case Study of Nicolas Novikov, 2014; Kultura wobec postępu i modernizacji. Rosja i Iran w perspektywie porównawczej, Kraków 2013; Irańska inteligencja w XIX w. i Rewolucja Konstytucyjna (1905-1911), Kraków 2010; Inteligencja a kultura. O problemach samoidentyfikacji dziewiętnastowiecznej inteligencji rosyjskiej, Kraków 2008; A. Awdiejew, Gramatyka interakcji werbalnej, Kraków 2004; B. Brążkiewicz, Choroba psychiczna w literaturze i kulturze rosyjskiej, Kraków 2011; Psychiatria radziecka jako instrument walki z opozycja politycznq 1918-1984, Toruń 2004; J. Diec, Konserwatywny nacjonalizm: studium doktryny w świetle myśli politycznej Igora Szafariewicza, Kraków 2013; Cywilizacje bez okien. Teoria Mikołaja Danilewskiego i późniejsze koncepcje monadycznych formacji socjokulturowych, Kraków 2003; K. Duda, Szkice o prozie rosyjskiej XXI wieku. Ulicka, Szyszkin, Pielewin, Minajew, Sienczyn, Kuricyn, Starobiniec..., Kraków 2017; Andriej Amalrik, rosyjski dysydent, Kraków 2010; J. Gordziejew, Цывільна-вайсковыя парадкавыя камісіі ў Вялікім Княстве Літоўскім у часы Чатырохгадовага сойма (1789-1792), Смаленск 2014; Тапанімія старажытнай Гародні (XII-XVIII cmcm.), Гродна 2013; Komisje Porzqdkowe Cywilno-Wojskowe w Wielkim Księstwie Litewskim w okresie Sejmu Czteroletniego (1789-1792), Kraków 2010; Магдэбургская Гародня (сацыяльная тапаграфія і маёмасныя адносіны уу 16-18 cm.), Гародня - Wrocław 2008; A. Jach, Rosja 1991-1993: walka o kształt ustrojowy państwa, Kraków 2011; K. Kosowska, Obraz życia szlachcianek rosyjskich w literaturze: od Piotra Wielkiego do Mikołaja I, Kraków 2012; M. Kowalska, Aleksander Sołżenicyn: homo sovieticus i człowiek sprawiedliwy, Toruń 2011; H. Kowalska-Stus, Czełowiek. Kultura. Cerkow'. Prawosławnaja pierspiektiwa, Saarbrücken 2012; Kultura i eschatologia. Moskwa wieku XVII, Kraków 2007; A. Krzywdzińska, Wizerunek Rosji i Stanów Zjednoczonych w polskich tygodnikach opinii po 1991 roku, Kraków 2012; L. Liburska, Kultura i inteligencja rosyjska. O pisarstwie Lidii Czukowskiej, Kraków 2003; L. Macheta, Demon południa i zafałszowanie egzystencji. O acedii starożytnego mnicha i zbędności inteligenta rosyjskiego XIX wieku, Kraków 2003; L. Madej, Rosyjski garnizon wojskowy w Częstochowie w latach 1831/1832-1914, Kraków 2009; A. Malska-Lustig, Ameryka oczami emigrantów rosyjskich trzeciej fali, Kraków 2004; D. Romanowski, Антоний Храповицкий. Философия, богословие, культура, Kraków 2013; Trzeci Rzym. Rozwój rosyjskiej idei imperialnej, Kraków 2013; Odnaleźć człowieka w człowieku: obraz bohatera w twórczości Mikołaja Gogola, Oświęcim 2009; M. Smoleń, Rosyjska inteligencja liberalna i radykalna w XIX i na poczq̨tku XX wieku, Kraków 2010; L. Suchanek, Anioły, biesy i prawda. Pisarstwo Jurija Drużnikowa, Kraków 2007; E. Żak, Mieszkańcy rosyjskiej świadomości zbiorowej XX i XXI wieku. Bohater kryminałów Aleksandry Marininej i Borysa Akunina, Kraków 2014.

${ }^{24}$ Podaję w porządku chronologicznym, poczynając od najdawniejszych: Картина мира и человека в литературе и мысли русской эмиграции. Obraz świata i człowieka 
Rosjoznawstwo - i tym różni się ono od tradycyjnie rozumianych badań slawistycznych - zapewnia integralną wiedzę o Rosji, jakiej nie daje żadna $z$ dotychczas istniejących dyscyplin. Ukazują one bowiem z reguły jeden aspekt, rosjoznawstwo natomiast obejmuje swym zasięgiem Rosję jako całość, a więc wieloaspektowo. Jest z założenia interdyscyplinarne, a ogląd Rosji dokonywany jest z perspektywy głównie kulturoznawcy, filologa (literaturoznawcy i językoznawcy), historyka, historyka sztuki, historyka idei, ale także - politologa.

Podstawowy przedmiot na krakowskich studiach rosjoznawczych stanowi kultura, od epoki bizantyńsko-ruskiej do kultury radzieckiej (sowieckiej) i postradzieckiej (życie kulturalne współczesnej Rosji); jest także miejsce dla kultury ludowej i kultury masowej. Nauczanie historii obejmuje całe dzieje, od epoki najdawniejszej po czasy najnowsze. Ważną rolę odgrywa historia literatury, od epoki staroruskiej po współczesność. Do programu wchodzą takie przedmioty, jak dzieje sztuki, teatru, filmu. Jest również blok przedmiotów poświęconych myśli filozoficznej i Rosyjskiej Cerkwi Prawosławnej oraz innym konfesjom, a także duchowości i mentalności. Przedmioty politologiczne obejmują doktryny polityczne, zagadnienie państwa i prawa. W rosjoznawstwie krakowskim specjalne miejsce przypada emigrantologii. Jako samodzielne całostki bądź elementy w zagadnieniach szerszych uwzględniane być muszą temat inteligencji rosyjskiej i problematyka związków polsko-rosyjskich, czy - w miarę możliwości - zagadnienie gospodarki i systemu ekonomicznego. Wiedza językoznawcza przekazywana

w literaturze i myśli emigracji rosyjskiej, red. A. Dudek, Kraków 2003; Rosjoznawstwo. Wprowadzenie do studiów nad Rosjq. Podręcznik akademicki, red. L. Suchanek, Kraków 2004; Kultura rosyjska w ojczyźnie i diasporze. Księga jubileuszowa dedykowana Profesorowi Lucjanowi Suchankowi, red. L. Liburska, Kraków 2007; Profesor doktor habilitowany Lucjan Suchanek. Zarys biografii naukowej. Spis publikacji, oprac. K. Duda, A. Malska-Lustig, Kraków 2007; Kultura rosyjska w ojczyźnie i diasporze. Księga jubileuszowa dedykowana Profesorowi Lucjanowi Suchankowi, t. 2, red. K. Duda, Kraków 2008; Idea i komunikacja w języku i kulturze rosyjskiej, red. A. Dudek, Kraków 2010; Idee konserwatywne w Rosji, red. A. Raźny, Kraków 2010; Fiodor Dostojewski i problemy kultury, red. A. Raźny, Kraków 2011; Rozpad ZSRR i jego konsekwencje dla Europy i świata, cz. 1: Federacja Rosyjska, red. A. Jach, Kraków 2011; Rozpad ZSRR i jego konsekwencje dla Europy i świata, cz. 2: Wspólnota Niepodległych Państw, red. M. Smoleń, M. Lubina, Kraków 2011; Rozpad ZSRR i jego konsekwencje dla Europy i świata, cz. 3: Kontekst międzynarodowy, red. J. Diec, Kraków 2011; Rozpad ZSRR i jego konsekwencje dla Europy i świata, cz. 4: Reinterpretacja po dwudziestu latach, red. A. Jach, M. Kuryłowicz, Kraków 2012; Rosyjskie siły zbrojne: aspekty wewnętrzne i kontekst polski, red. A. Jach, Kraków 2013. 
jest inaczej niż na filologiach, a więc $w$ aspekcie komunikacyjnym, i obejmuje takie problemy, jak media, nowomowa i język rosyjski dziś. Dużą wagę przykłada się do praktycznej nauki języka rosyjskiego oraz do praktyki tłumaczenia.

Chciałbym się na chwilę zatrzymać na intelektualnych i metodologicznych źródłach inspiracji krakowskiego rosjonawstwa. W badaniach rosjoznawczych potrzebne było nowe podejście, które pozwoliłoby głęboko i wszechstronnie opisać człowieka, system i państwo. Państwo w okresie radzieckim, z założenia ateistyczne, w którym ateizm ze zjawiska indywidualnego stał się masowy i wojujący.

Badania, w których człowiek traktowany jest wyłącznie jako ens sociale, były dla rosjoznawstwa niewystarczające i dlatego podstawą opisu stała się tu antropologia filozoficzna, to znaczy filozofia człowieka, szczególnie personalizm w różnych jego odmianach (Martin Buber, Maurice Nédoncelle, Helmuth Plessner). Anna Raźny wprowadziła do obiegu rosjoznawczego takich myślicieli, jak Maks Scheller czy Emmanuel Levinas, a także Søren Kierkegaard. W jej pracach bardzo silnie odzwierciedla się zainteresowanie metafizyką. Bliską jej postawę przyjmuje Lidia Macheta.

Spośród współczesnych polskich uczonych i myślicieli, filozofów wymienić trzeba Karola Wojtyłę - papieża Jana Pawła II, przedstawiciela personalizmu tomistyczno-fenomenologicznego, a także reprezentanta personalizmu fenomenologicznego - Józefa Tischnera, którego kontakty z krakowskimi rosjoznawcami były bardzo bliskie. To nie tylko on oddziałał na rosjoznawców, ale i - głównie dzięki prof. Annie Raźny - sam zainteresował się dziełami Dostojewskiego czy koncepcją homo sovieticus, którą zresztą przedstawiał zupełnie inaczej, niż ma to miejsce w rosjoznawstwie, np. w pracach Lucjana Suchanka.

Bardzo inspirującą rolę odegrał wybitny tomista o. Mieczysław Krąpiec i uczeni z kręgu lubelskiego fenomenologicznego personalizmu. Z polskich uczonych wspomnieć tu trzeba fenomenologa Romana Ingardena.

Duży wpływ na ideowe i intelektualne oblicze krakowskiego rosjoznawstwa miała filozofia religijna rosyjskiego renesansu kulturowego - Nikołaja Bierdiajewa, Siergieja Bułgakowa, Pawła Fłorienskiego, Gieorgija Fłorowskiego, Siemona Franka, Nikołaja Łosskiego, Lwa Szestowa. Dla kształtowania się twórczego laboratorium badawczego rosjoznawców znaczenie miały koncepcje rosyjskiej tartusko-moskiewskiej szkoły semiotyki (Boris Jegorow, Jurij Łotman, Boris Uspienski). Wspomnieć należy również Michaiła Bachtina, zwłaszcza jego koncepcję dialogu. 
Spośród polskich badaczy kultury i literatury rosyjskiej wymienić trzeba Wacława Lednickiego; nie sposób nie wspomnieć też prof. Ryszarda Łużnego, który do badań rosjoznawczych wprowadził problematykę sacrum i szerokie zainteresowanie filozofią rosyjską. Wcześniej robił to Andrzej Walicki, do którego prac sięgało wielu krakowskich rosjoznawców. Dla badaczy epok dawniejszych ważny był dorobek prof. Wiktora Jakubowskiego.

Zasygnalizowane dotąd koncepcje naukowe pozwalały opisywać jeden z elementów rosyjskiej i radzieckiej rzeczywistości - człowieka. Do analizy systemu i państwa potrzebne były inne inspiracje. Bardzo pomocne okazały się prace przedwojennych polskich sowietologów i historyków: Jana Kucharzewskiego z wileńskiego Instytutu Wschodniej Europy, a szczególnie Mariana Zdziechowskiego, wcześniej związanego z Krakowem, członka PAU - członka Klubu Słowiańskiego. Członkiem Klubu Słowiańskiego był także Feliks Koneczny, którego spuścizna była inspiracją dla krakowskich badaczy cywilizacji rosyjskiej. Jednym ze współczesnych inspiratorów rosjoznawstwa był o. Józef Bocheński. Był nim także wybitny badacz psychiatra Antoni Kępiński.

Wymieńmy jeszcze kilku myślicieli, zarówno polskich, jak i rosyjskich, takich jak Jerzy Szacki, Siergiej Awierincew, Siergiej Chorużyj. To jednak wciąż niepełne spektrum badaczy i koncepcji kształtujących krakowskie rosjoznawstwo.

Jestem przekonany, że możemy mówić o krakowskiej szkole rosjoznawstwa i emigrantologii. Stała się ona znakiem wizerunkowym ważnej jednostki badawczej Wydziału Studiów Międzynarodowych i Politycznych, jego odłamu kulturoznawczego. Napisałem o tym w artykule zamieszczonym w znanym czeskim piśmie - „Novaja rusistika” 25 .

$Z$ rosjoznawstwem związana jest ściśle emigrantologia, mająca również charakter interdyscyplinarny ${ }^{26}$. Podobnie jak rosjoznawstwo, narodziła się

${ }^{25}$ L. Suchanek, Краковская исследовательская школа россиеведения и эмигрантологии, „Novaja rusistika. Nová rusistika. Mieżdunarodnyj żurnał sowriemiennoj fiłołogiczeskoj i arealnoj rusistiki" 2013 (Brno), Suplementum, s. 23-34; zob. także idem, Краковская исследовательская школа россиеведения и эмигрантологии, [w:] Situace mezinárdní slavisiky: kto je vinen a co dělat. Antologie príspevků, materiál a dokumentu, red. I. Pospíšil, Brno 2015, s. 85-96.

${ }^{26} \mathrm{O}$ emigrantologii zob. idem, Emigrantołogija, [w:] Idiei v Rossii. Ideas in Russia. Idee w Rosji. Leksykon rosyjsko-polsko-angielski, t. 9, red. J. Dobieszewski, Łódź 2015, s. 496-499; idem, Emigracja. Emigrantologia. Komisja Emigrantologii Słowian, „Slavia Orientalis” LXIII, $\mathrm{nr} 2$ 2, 2014, s. 173-189; idem, Słowiańska emigrantologia, 
w Krakowie. Przypomnijmy, że działał tu, najpierw na Wydziale Filologicznym, potem na Wydziale Studiów Międzynarodowych i Politycznych, kierowany przez Lucjana Suchanka zespół badawczy, zajmujący się spuścizną emigracji trzeciej fali i tamizdatem. Termin „emigrantologia” został wprowadzony i scharakteryzowany przez Lucjana Suchanka na XII Międzynarodowym Kongresie Slawistów w Krakowie w 1998 roku. Od tego czasu używany jest szeroko $w$ nauce, w slawistyce światowej. O emigrantologii jako dyscyplinie uniwersyteckiej i nauce mówiłem na XIII Kongresie Slawistów w Lublanie (2003), a na XIV Kongresie Slawistów w Macedonii (2008) wygłosiłem referat Emigrantologia: osiqgnięcia i nowe perspektywy. Między Kongresem w Krakowie a w Ochrydzie. 1998-200827.

Dorobek emigracji daje możliwość prowadzenia badań wieloaspektowych. Szeroko już dziś rozwinięte są w wielu krajach badania historyczne, źródłowe, archiwalne. Prace emigrantologiczne obejmują relacje o życiu emigrantów: z antropologicznego punktu widzenia szczególnie ważne są rozważania na temat emigranta jako typu człowieka, emigrantologia bowiem to nauka o warunkach egzystencji na obczyźnie ${ }^{28}$. Publikacje dotyczą różnych form wielorakiej działalności i aktywności, w tym szczególnie organizacyjnej i edytorsko-wydawniczej. Opisują i oceniają spuściznę pisarską, zarówno beletrystyczną, jak i publicystyczną, eseistyczną, dokumentalną, filozoficzną, religijną, naukową. Przedstawiają zróżnicowanie polityczno-ideologiczne poszczególnych licznych partii i ruchów ideowo-filozoficznych,

[w:] Współczesne literaturoznawstwo slawistyczne, red. L. Suchanek, Kraków 2004, s. 73-88; idem, Комиссия эмигрантологии славян Международного комитета славистов, „Emigrantologia Słowian” 1, 2015, s. 9-12.

${ }^{27}$ Idem, Emigrantologia: osiqgnięcia i nowe perspektywy. Między Kongresem w Krakowie a w Ochrydzie. 1998-2008, [w:] Z polskich studiów slawistycznych. Literaturoznawstwo. Kulturologia. Folklorystyka, red. L. Suchanek, K. Wrocławski, Warszawa 2008, s. 159-169. Zob. także idem, Emigrantologia i literaturoznawstwo, [w:] Studia z historii literatury i kultury Słowian, red. B. Czapik-Lityńska, Z. Darasz, Katowice 2000, s. 42-45; idem, Słowiańska emigrantologia, [w:] Współczesne literaturoznawstwo slawistyczne, red. L. Suchanek, Kraków 2004, s. 73-88; idem, Człowiek w traumie. Emigrantologia na przykładzie emigracji rosyjskiej dwudziestego wieku, "Ethos” 3-4 (87-88), 2009, s. 230-244; idem, Rossijewiedienije i emigrantołogija. Nowyje formy issledowanij i didaktiki w pol'skoj sławistikie, „Novaja rusistika. Nová rusistika. Mieżdunarodnyj żurnał sowriemiennoj fiłołogiczeskoj i arealnoj rusistiki" 2012 (Brno), Suplementum, s. 17-21.

${ }^{28}$ Idem, Miesto antropołogii w emigramtołogiczeskich issledovanijach, [w:] Руска дијаспора и словенски свет. Зборник радова. Учредитель Петра Бунњк, Београд 2013, s. 11-21. 
ugrupowań literackich, stowarzyszeń zawodowych i twórczych. Opisywana jest sytuacja Cerkwi prawosławnej. W emigrantologii niezwykle szeroko rozwinęły się badania nad literaturą, zarówno w płaszczyźnie światopoglądowo-ideowej, jak i w sferze formy. Bardzo interesujące poznawczo są badania tematologiczne, które pozwalają uchwycić odrębność literatury emigracyjnej, jej specyfikę w stosunku do literatury metropolii (literatury krajowej).

W grudniu 2008 roku przy Komitecie Słowianoznawstwa PAN została utworzona Komisja Emigrantologii Słowian, której przewodniczącym został Lucjan Suchanek, inicjator powołania takiej komisji. We wrześniu 2013 roku Komisja Emigrantologii Słowian została afiliowana przy Międzynarodowym Kongresie Slawistów - w ten sposób stała się komisją międzynarodową. Członkami komisji jest wielu krakowskich rosjoznawców, którzy tworzą najsilniejszą grupę badaczy emigrantologów w Polsce: przewodniczącym został Lucjan Suchanek, a w strukturach Zarządu Komisji znaleźli się Andrzej Dudek, jako przedstawiciel polskiej emigrantologii, Anna Raźny, Hanna Kowalska-Stus i Katarzyna Duda. Niektórzy z nich wchodzą do redakcji pisma „Emigrantologia Słowian”29.

Istotne zmiany w krakowskim rosjoznawstwie zachodzą w roku 2012; tu właściwie zaczyna się nowy etap jego dziejów: wraz z końcem kadencji jako dyrektora prof. Anny Raźny, kiedy w wyborach kierownictwo instytutu kulturoznawczego powierzono politologowi, prof. Joachimowi Diecowi. Zainteresowania naukowe tego rosjoznawcy, ukształtowanego w nurcie filologii i kulturoznawstwa, zaczęły ewoluować w kierunku politologii (habilitacja z politologii). Z punktu widzenia Katedry Rosjoznawstwa było to wówczas pożądane, zniknęła bowiem potrzeba zatrudniania pracownika spoza jednostki dla przedmiotów politologicznych. Z biegiem czasu jednak, wbrew potrzebom kulturoznawczego profilu katedry, zaczęła wzrastać liczba politologów, to znaczy osób mających doktoraty z politologii, których promotorami byli nieraz kulturoznawcy. Mimo posiadania stopnia doktora politologii prowadzili oni zajęcia kulturoznawcze. Stało się tak między innymi dlatego, że młodzi pracownicy instytutu nie mogli zdobywać doktoratów z kulturoznawstwa. Po długich staraniach wydział zdobył jednak uprawnienia do nadawania stopnia doktora kulturoznawstwa.

${ }^{29} \mathrm{Idem}$, Комиссия эмигрантологии славян Международного комитета славистов, „Emigrantologia Słowian” 1, 2015, s. 9-12; idem, Emigracja. Emiograntologia. Komisja Emigrantologii Słowian, „Slavia Orientalis” LXIII, nr 2, 2014, s. 173-189. 
Zmiana na stanowisku dyrektora w 2012 roku nie była jedynie, jak często $w$ takich przypadkach bywa, zmianą personalną, która $w$ zasadzie nie zmienia status quo - nastąpiło bowiem przeobrażenie wizji instytutu, co odbiło się na jego kulturoznawczym profilu. Profesor Anna Raźny jako dyrektor Instytutu Rosji i Europy Wschodniej była strażniczką programu rosjoznawczego. Byłem przekonany, że stanowi on wspólną wartość wszystkich pracowników instytutu. Miałem wrażenie, że jednakowo patrzymy na rosjoznawstwo, że dzielimy przekonanie o jego kulturoznawczym profilu, bo tak musi być w przypadku wspólnoty, do której się należy i z którą trzeba się identyfikować i być wobec niej lojalnym. Okazało się jednak, że nie wspólnotowość duchowo-ideowa jest najważniejsza, i powierzając kierownictwo instytutu kulturoznawczego politologowi, ryzykowano, że mogą nastąpić istotne zmiany w ugruntowanym kulturoznawczym modelu kształcenia - i tak się rzeczywiście stało.

Zmiany zawsze są możliwe i nawet pożądane, nie mogą one jednak zniekształcać istoty i sensu całościowej koncepcji, która się przyjęła i ma spore osiągnięcia. Wraz z nową dyrekcją rozpoczął się stopniowy demontaż kulturoznawczego programu nauczania, właściwie jego dewastacja. Szczególnie, choć nie tylko, zaskoczyło mnie podejście do emigrantologii, która jest i powinna być jednym z wizerunkowych znaków krakowskiego rosjoznawstwa. Na szczęście dzięki osobom doceniającym jej wagę pozostała w programie.

Rosjoznawstwo od samego początku działa w kulturoznawczym komponencie wydziału, który ze swej natury nie jest homogeniczny. Nie powinno ono zmierzać $w$ stronę modelu politologicznego - $w$ takiej postaci mogłoby egzystować na politologii. Przypomnę, że rosjoznawstwo powstato po to, by w zakresie charakterystyki i oceny Rosji jego absolwentów zaopatrzyć w wiedzę i argumenty właśnie kulturologiczne. Bo tylko tak można ten kraj i jego mieszkańców w pełni zrozumieć. W dzisiejszym dyskursie o Rosji poziom interpretacji politologicznej znacznie się poprawił, dalej jednak brak w nim argumentów natury kulturoznawczej - i takie musi dawać rosjoznawstwo jako kierunek kulturoznawczy.

Zabiegi organizacyjne zmierzające do tego, by kulturoznawczy charakter rosjoznawstwa ograniczyć czy zmienić, osiągnęły apogeum po kolejnym wyborze politologa na nową kadencję dyrektora instytutu. Przekształceń, które się dokonały i dokonują w instytucie, nie można tłumaczyć wyłącznie faktem, że liczba kandydatów na rosjoznawstwo zmalała - dziś to zjawisko powszechne. Powstaje pytanie, co zrobiono, by rosjoznawstwo lepiej 
i efektywniej spopularyzować. Demagogiczny jest również argument, że studenci domagają się zmian.

Ostatnia decyzja instytutu, zatwierdzona przez Radę Wydziału, przeobraża w sposób zasadniczy charakter rosjoznawstwa. Według nowego modelu tylko $49 \%$ przedmiotów może mieć charakter kulturoznawczy, a $51 \%$ to przedmioty z dziedziny nauk społecznych. Wywołuje to zdziwienie: mimo iż liczba politologów w instytucie została zwiększona ponad miarę, nie ma w nim tylu specjalistów reprezentujących nauki społeczne, by zapewnić obsadę dla 51\% przedmiotów. Jest natomiast - przy zachowaniu proporcji 51 do 49 - za dużo kulturoznawców. Dążąc do zmian, nie można wysuwać argumentu, że należy się przekwalifikować - to jest oczywiście możliwe, lecz wymaga długiego czasu na pogłębianie wiedzy. Taka sytuacja grozi wyraźnym obniżeniem poziomu, który w przypadku rosjoznawstwa kulturoznawstwa - był wysoki.

Ewolucja rosjoznawstwa poszła w złym kierunku, zatraciło ono swój charakter i stało się mało wyraziste. Nie trzeba było wcale zmieniać jego istoty poprzez nadanie mu kształtu kierunku hybrydowego. Należało podjąć próbę bardziej realną i gwarantującą dotychczasowy poziom.

Dla krakowskiego rosjoznawstwa istnieje inna perspektywa. Mieliśmy ją w planach już dawno, gdy Katedra Rosjoznawstwa zwróciła się do władz resortu o powołanie studiów nad cywilizacjami - wtedy jednak, gdy miało miejsce silne sformalizowanie, jeśli idzie o wykaz kierunków studiów, nie spotkało się to ze zrozumieniem. Dziś, gdy autonomia uczelni jest znacznie silniejsza, można do tego powrócić.

Jest to niezbędne dlatego, że termin „kulturoznawstwo” jest w polskiej praktyce uniwersyteckiej niejednoznaczny i z reguły bywa rozumiany wąsko. W założeniach programowych krakowskiego rosjoznawstwa kulturoznawstwo było traktowane szeroko, jako całokształt duchowego dorobku społeczeństwa, obejmującego kulturę duchową: a więc literaturę i wszelkiego rodzaju piśmiennictwo, różne rodzaje sztuk (sztuki plastyczne, teatr, muzykę, film), ale także wierzenia, wytwory umysłu (filozofię, ideologie, systemy wartości), jak również kulturę polityczną. W aktualnej postaci rosjoznawstwa widoczne jest koncentrowanie się tylko na poszczególnych jego aspektach, które w znacznym stopniu określić można jako politologiczne.

Przy tradycyjnym rozumieniu rosjoznawstwa jako sfery kulturoznawstwa kultura bliska jest cywilizacji. Jak wiemy, niekiedy te dwa pojęcia traktowane są jako synonimy. Czasem, jak w koncepcji Oswalda Spenglera, 
pojmowane są jako terminy służące do oznaczenia różnych faz tego samego procesu. Historia ludzkości to dzieje cywilizacji, które stanowiły dla ludzi najszersze ramy do określania własnej tożsamości. Rozmaicie je definiowano, powszechnie jednak wszelkie cywilizacje utożsamiano $z$ wielkimi religiami świata, będącymi ich fundamentami. Tak jest w przypadku chrześcijaństwa, islamu, hinduizmu, konfucjonizmu. Każda cywilizacja stanowi całość; mają one jednak określony stopień integracji - znamienne jest, że w ich obrębie można łączyć różne państwa. Cywilizacje określane są przez obiektywnie wspólne elementy, takie jak język, religia, historia, obyczaje czy instytucje społeczne.

W dziejach ludzkości było wiele cywilizacji, od sumeryjskiej i egipskiej zaczynając. Wiele z nich odeszło w przeszłość. Różne są poglądy co do liczby cywilizacji, co do okresu ich trwania i etapów, przez jakie przechodziły. We wszystkich jednak, choć rozmaicie były nazywane i rozumiane, pojawia się cywilizacja, która wiąże się z Rosją na różnych etapach jej rozwoju historycznego. Jeden z najwybitniejszych badaczy cywilizacji, Arnold J. Toynbee, autor dwunastotomowego dzieła The Study of History (Studium Historii, 1934-1954), wśród 21 cywilizacji wymienia prawosławną, ortodoksyjno-chrześcijańską. Oswald Spengler w swoim dwutomowym dziele Der Untergang des Abendlandes (Zmierzch Zachodu, 1918-1922) mówi o cywilizacji rosyjskiej (rosyjsko-syberyjskiej). Feliks Koneczny (O wielości cywilizacji, 1935) wyróżnia siedem istniejących aktualnie cywilizacji, a wśród nich bizantyńską i turańską. Ta ostatnia, jego zdaniem, stanowi absolutne przeciwieństwo łacińskiej. Carroll Quigley w swojej pracy The Evolution of Civilizations (1961) wyróżnia 16 cywilizacji, a wśród nich prawosławną ${ }^{30}$. Najgłośniejszy ostatnio znawca problemu, Samuel Huntington (The Clash of the Civilisations - Zderzenie cywilizacji, 1993), wśród siedmiu głównych cywilizacji współczesności wyróżnia prawosławną, której ośrodkiem jest Rosja.

Na koniec zwróćmy jeszcze uwagę na nazwę instytutu. Zajmuje się on studiami nad Rosją, ukrainoznawstwo stało się odrębną jednostką wydzia$ł u$, a białorutenistyka nie przekształciła się w samodzielną dyscyplinę. Pod nazwę Instytut Rosji i Europy Wschodniej nie podpada w pełni także Katedra Badań nad Obszarem Euroazjatyckim. Obecna nazwa instytutu jest więc myląca i powinna przeto brzmieć: Instytut Rosjoznawstwa. Podejście do rosjoznawstwa z perspektywy studiów nad cywilizacją uwiarygodnia

${ }^{30}$ Zob. A. Skorupka, Wprowadzenie do filozofii cywilizacji Carrolla Quigleya, „Rocznik Filozoficzny Ignatianum - The Ignatianum Philosophical Yearbook” 2, 2014, s. 91-110. 
wprowadzenie do programu paralelnych studiów: nad cywilizacją nazywaną przez Konecznego turańską, a określaną w propozycji instytutu jako euroazjańska. Jednak kształt propozycji musi ulec znacznym modyfikacjom w kierunku cywilizacyjnego, kulturoznawczego charakteru - kosztem politologicznego.

\title{
RUSSIAN STUDIES = CULTURAL STUDIES. RUSSIAN STUDIES AT THE JAGIELLONIAN UNIVERSITY IN KRAKOW (1990-2017)
}

\begin{abstract}
The subject of the article is the history of the development of Russian cultural studies (RCS) in Krakow, initiated at the turn of the $20^{\text {th }}$ and $21^{\text {st }}$ centuries. The collective achievement created by scientists with mainly philological backgrounds over the years have been enriched and expanded by content from other scientific disciplines. This ultimately formed a multidisciplinary face of RCS. In the article, the most important figures and publications are mentioned that contributed to building a significant curriculum of Russian cultural studies in Krakow. The specificity of the curriculum, its multidimensionality and humanistic-social approach make it a rich reservoir of knowledge which helps one to understand culture in its Russian form.
\end{abstract}

Key words: Russian studies, interdisciplinarity, multidimensionality 